\title{
Breast reconstruction with the omentum flap: a case report with unsatisfactory outcome and review of the literature
}

\author{
Rossella Spinelli · Monika Lanthaler · Christoph Tasch · Agnese Nitto · Gerhard Pierer · Thomas Bauer
}

Received: 26 March 2019 / Accepted: 20 November 2019 / Published online: 11 December 2019

(C) The Author(s) 2019

\begin{abstract}
Summary
Background Recently, breast reconstruction with the greater omentum flap has gained more attention, although it has been only rarely reported in the literature. An unpleasant case presented by us here prompted us to perform a literature search on breast reconstruction with the omentum flap concerning postoperative results and complication rates.

Case presentation We here present the case of a $46-$ year-old woman who presented with severe infection 3 months after omentum flap reconstruction in a distant local hospital. Intraoperative revision showed an inflammatory, completely necrotic flap that had to be removed.

Conclusion The literature review shows that the omentum flap can be reasonably used only in onesided reconstructions of very small breasts. Due to the limited indications, unpredictable flap volume, and our negative experience, we recommend that this type of reconstruction be used with restraint.
\end{abstract}

Keywords Breast reconstruction - Autologeous tissue $\cdot$ Literature research $\cdot$ Complications . Postoperative outcome

\section{Introduction}

The increasing detection of early breast cancer due to systematic screening allows less invasive surgery, such as breast-conserving surgery (BCS) and nipple-spar-

\section{R. Spinelli, M. Lanthaler, and T. Bauer contributed equally} for first authorship.

R. Spinelli, MD · M. Lanthaler, MD, PD ( $₫) \cdot$ C. Tasch, MD ·

A. Nitto, MD · Prof. G. Pierer, MD · T. Bauer, MD

Innsbruck Medical University Hospital,

Anichstraße 35, 6020 Innsbruck, Austria

monika.lanthaler@i-med.ac.at ing and skin-sparing mastectomy [1]. Consequently, an increasing number of patients choose the option of immediate breast reconstruction. Generally, three different approaches are considered for breast reconstruction: implants or expander reconstruction, free or pedicled flaps with vascularized autologous tissue, and autologous fat transfer (AFT) [2]. Autologous tissue reconstruction is cost effective, achieves good and natural cosmetic results, and is more suitable in case of radiotherapy [3].

The principal methods of breast reconstruction using autologous tissue include the latissimus dorsi musculocutaneous flap (LDL), flaps of lower abdominal tissue such as transverse rectus abdominis myocutaneous (TRAM) flaps, pedicled (pTRAM) or free (fTRAM), and perforator flaps.

Most women requiring tissue transfer for breast reconstruction are candidates for perforator flaps. The deep inferior epigastric perforator (DIEP) flap is supplied by intramuscular perforators from the deep inferior epigastric artery and vein. The superficial inferior epigastric artery flap (SIEA) is based on the superficial inferior epigastric artery and vein, which arise from the common femoral artery and saphenous bulb. GAP flaps are based on perforators from either the superior or the inferior gluteal artery (SGAP and IGAP).

Breast reconstruction with the omentum flap has rarely been reported in the literature. The greater omentum can be harvested either by standard open approach or by laparoscopy, with decreased risk of donor site deformity and morbidity, and is transferred to the breast through a tunnel created from the medial end of the inframammary fold, toward the xiphoid process, to the abdominal cavity. The laparoscopically harvested omental flap (LHOF) may be pedicled on the gastroepiploic vessels, or free (LHOFF) when the right gastroepiploic pedicle is anastomosed with the 


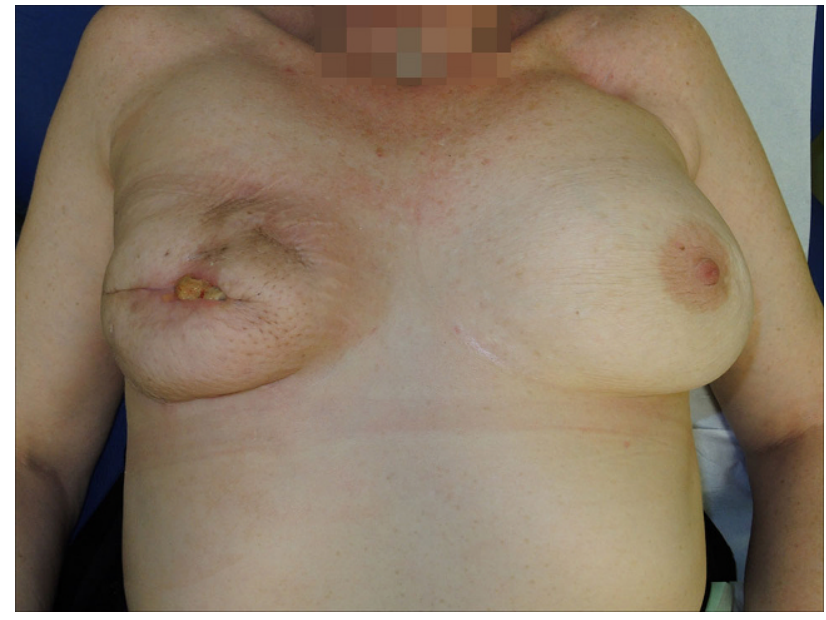

Fig. 1 Clinical presentation 3 months after reconstruction with the omentum flap

receiving vessels in the chest wall, like the thoracic dorsal or the internal mammary vessels.

\section{Case presentation}

A 46-year-old woman presented at our outpatient clinic with a severe infection of the surgical wound at the submammary fold 3 months after autologous breast reconstruction with the greater omentum, which had been performed at a different institution. She had already had multiple local wound debridements and several antibiotics, with limited results. At clinical examination she had a non-healing breast wound and the flap was necrotic (Fig. 1). Wound revision was planned to remove the necrotic flap. Microbiological culture of the infected tissues revealed an infection with Achromobacter xylosoxidans. A 2week course of piperacillin/tazobactam was administered. Thereafter, 2 weeks postoperatively, the wound had completely healed. The patient declined any further reconstructive surgery despite poor cosmetic results (Fig. 2).

\section{Methods}

\section{Literature search strategy}

Two independent researchers conducted a systematic review in the PubMed, Embase, and Cochrane Library databases, adhering to the PRISMA statement, and assessed the methodological quality of the studies according to the Grading of Recommendations Assessment, Development, and Evaluation (GRADE) criteria [4]. The search was conducted from January 2014 to December 2018 with the following search terms: "omentum," "omental," "reconstruction," and "breast."

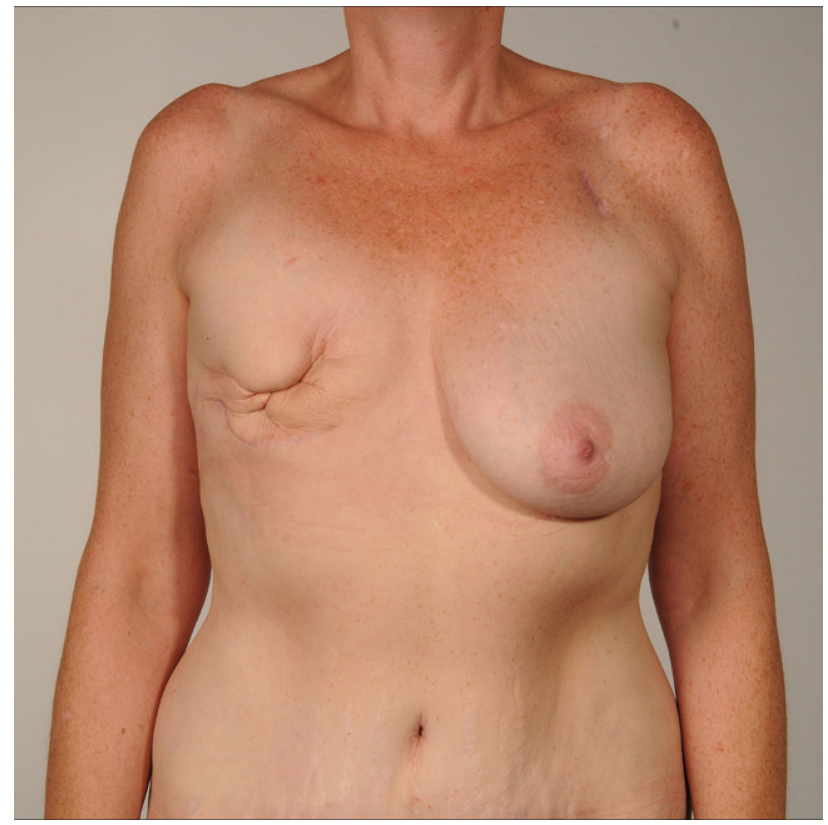

Fig. 2 Postoperative result after operative revision with removal of the necrotic flap

\section{Inclusion criteria}

The data search was restricted to studies reporting on breast reconstruction with the omentum flap. Experimental studies in animals were excluded. Abstracts of the references retrieved were reviewed and the full text of all potentially relevant studies was analyzed for eligibility. Information from each study was extracted using a standardized data extraction form. Authors were not contacted.

\section{Data extraction}

Articles not reporting original data, such as literature reviews, editorials, and comments, and studies with reconstruction of the thoracic wall were excluded. Moreover, when several articles used duplicate data, only one of the articles was included. Only articles describing a breast reconstruction with pedicled or free omental flap techniques were retained for the final analysis. After inclusion, we retrieved from each study the following variables (when available): year of publication, number of patients, type of procedure, patient characteristics (body max index, BMI), type of study, technique used for omental flap harvesting, flap design, flap weight, surgical complications, cosmetic results, and follow-up (Table 1).

\section{Results}

A total of seven articles were included for the final analysis.

Fifty-seven (19.4\%) complications occurred in a total of 293 patients, including total or partial flap 
Table 1 Literature search on breast reconstruction with the omentum flap

\begin{tabular}{|c|c|c|c|c|c|c|c|c|c|}
\hline Article & $\begin{array}{l}\text { Year of } \\
\text { publica- } \\
\text { tion }\end{array}$ & $\begin{array}{l}\text { Patients } \\
\text { and flap } \\
\text { design }\end{array}$ & $\begin{array}{l}\text { Body } \\
\text { mass } \\
\text { index }\end{array}$ & Complications & $\begin{array}{l}\text { Oncologic } \\
\text { outcome }\end{array}$ & Cosmetic result & $\begin{array}{l}\text { Flap } \\
\text { weight }\end{array}$ & $\begin{array}{l}\text { Follow-up } \\
\text { (months) }\end{array}$ & $\begin{array}{l}\text { OP } \\
\text { time } \\
\text { (min) }\end{array}$ \\
\hline $\begin{array}{l}\text { Ni C [14] } \\
\text { (China) }\end{array}$ & 2018 & 7 free flaps & n.d. & Graft infection $(n=1)$ & $\begin{array}{l}\text { No recur- } \\
\text { rence }\end{array}$ & $\begin{array}{l}\text { Excellent }(n=4) \\
\text { Good }(n=2) \\
\text { Fair }(n=1)\end{array}$ & n.d. & $\begin{array}{l}\text { Average } \\
9 \text { (range } \\
3-13 \text { ) }\end{array}$ & 311 \\
\hline $\begin{array}{l}\text { Van Alphen } \\
\text { TC [9] (The } \\
\text { Nether- } \\
\text { lands) }\end{array}$ & 2017 & 6 free flaps & $21.3 \mathrm{~kg} / \mathrm{m}^{2}$ & $\begin{array}{l}\text { Flap necrosis }(n=1) \\
\text { Venous thrombosis }(n=1) \\
\text { Stinging }(n=1)\end{array}$ & $\begin{array}{l}\text { No recur- } \\
\text { rence }\end{array}$ & $\begin{array}{l}\text { Satisfactory } \\
(n=6)\end{array}$ & $224 \mathrm{~g}$ & $\begin{array}{l}\text { Average } \\
30.5\end{array}$ & 426.5 \\
\hline $\begin{array}{l}\text { Kim } H[11] \\
\text { (Korea) }\end{array}$ & 2017 & 5 free flaps & $21.7 \mathrm{~kg} / \mathrm{m}^{2}$ & Uneventful & $\begin{array}{l}\text { No recur- } \\
\text { rence }\end{array}$ & $\begin{array}{l}\text { Excellent/good } \\
(n=5)\end{array}$ & $\begin{array}{l}212 \mathrm{~g} \\
\text { (range } \\
104- \\
272 \mathrm{~g} \text { ) }\end{array}$ & $\begin{array}{l}\text { Average } \\
8.2 \\
\text { (range } \\
5-11 \text { ) }\end{array}$ & 298 \\
\hline $\begin{array}{l}\text { Zaha H [8] } \\
\text { (Japan) }\end{array}$ & 2017 & $\begin{array}{l}190 \text { pedi- } \\
\text { cled } \\
10 \text { free } \\
\text { flaps } \\
1 \text { sus- } \\
\text { pended }\end{array}$ & n.d. & $\begin{array}{l}\text { Vascular injury with flap loss }(n=2) \\
\text { Infection }(n=2) \\
\text { Chylous leakage }(n=1) \\
\text { Epigastric hernia }(n=2) \\
\text { Hematoma }(n=2) \\
\text { Partial flap necrosis }(n=10) \\
\text { Partial skin necrosis }(n=5) \\
\text { Fat necrosis }(n=11)\end{array}$ & $\begin{array}{l}\text { Local re- } \\
\text { currence } \\
(n=2)\end{array}$ & $\begin{array}{l}\text { Excellent/good } \\
(n=152) \\
\text { Fair/poor }(n=38) \\
\text { Volume insuffi- } \\
\text { ciency }(32.6 \%)\end{array}$ & $181 \mathrm{~g}$ & $\begin{array}{l}\text { Average } \\
90\end{array}$ & 203 \\
\hline $\begin{array}{l}\text { Li N [12] } \\
\text { (China) }\end{array}$ & 2017 & $\begin{array}{l}9 \text { free flaps } \\
1 \text { sus- } \\
\text { pended }\end{array}$ & n.d. & $\begin{array}{l}\text { Free flap necrosis }(n=1) \\
\text { converted to fat graft }(n=1) \\
\text { Hematoma }(n=1)\end{array}$ & $\begin{array}{l}\text { Distant } \\
\text { metastasis } \\
(n=1)\end{array}$ & $\begin{array}{l}\text { Excellent/good } \\
(n=9) \\
\text { Fair }(n=1)\end{array}$ & n.d. & n. d. & 373 \\
\hline $\begin{array}{l}\text { Zhang P } \\
{[13]} \\
\text { (China) }\end{array}$ & 2015 & $\begin{array}{l}40 \text { free } \\
\text { flaps }\end{array}$ & $22.8 \mathrm{~kg} / \mathrm{m}^{2}$ & Partial graft necrosis $(n=2)$ & $\begin{array}{l}\text { No recur- } \\
\text { rence }\end{array}$ & $\begin{array}{l}\text { Excellent/good } \\
(n=39) \\
\text { Fair }(n=1)\end{array}$ & n.d. & $\begin{array}{l}\text { Average } \\
15.6 \\
\text { (range } \\
6-36 \text { ) }\end{array}$ & 308 \\
\hline $\begin{array}{l}\text { Guan D } \\
{[10]} \\
\text { (China) }\end{array}$ & 2015 & $\begin{array}{l}24 \text { pedi- } \\
\text { cled flaps } \\
1 \text { sus- } \\
\text { pended }\end{array}$ & n.d. & $\begin{array}{l}\text { Mild epigastric discomfort }(n=4) \\
\text { Fat necrosis nodules }(n=3)\end{array}$ & $\begin{array}{l}\text { Local re- } \\
\text { currence } \\
(n=1) \\
\text { Metastasis } \\
(n=1)\end{array}$ & n.d. & n.d. & $\begin{array}{l}\text { Average } \\
32 \text { (range } \\
6-51 \text { ) }\end{array}$ & 310 \\
\hline
\end{tabular}

loss (17 cases, 5.8\%), fat necrosis with palpable nodules (14 cases, $4.77 \%$ ), partial skin necrosis (five cases, $1.7 \%$ ), hematoma (three cases, $1.02 \%$ ), infection (three cases, $1.02 \%$ ), two vascular injuries, two epigastric hernia, one vascular thrombosis, five cases of abdominal stinging or discomfort, and one chylous leakage.

We found a total of three cases of recurrence and two of distant metastasis. One patient died after 11 months. Only one work had a follow-up of more than 5 years. Five studies had a follow-up of less than 1 year with no oncologic results.

The mean operative time was $318.5 \mathrm{~min}$ (for free flaps $370.16 \mathrm{~min}$ ).

\section{Discussion}

Kirikuta et al. [5] first described the use of the greater omentum for breast reconstruction in 1961. Since then, the omentum flap has been used to treat congenital deformities of female breasts, after radiation treatment, and for partial breast reconstruction. It was also occasionally used to restore the thoracic cavity and the chest wall, mostly as a pedicled flap.

Claro et al. [6], in a literature review from January 1984 to December 2013, reported that before 2000, the greater omentum was used only as a last option for covering huge deformities resulting from mastectomy performed in women with advanced breast cancer. Initially, laparotomy was almost the only technique used. Successively, laparoscopy was more often performed for breast reconstruction in patients with early-stage breast cancer [7-9] and also for additional coverage of breast implants [10]. Interestingly, Claro et al. reported that flap necrosis is the most frequent complication (31.87\%), with the second most common complication being breast infection (19.05\%), followed by abdominal wall hernia (16.12\%) and bowel obstruction or ileus $(9.16 \%)$. Indeed, the author recommended breast reconstruction with the omentum only when muscular/myocutaneous or perforator flaps were not feasible.

In all the articles covered in the present review, spanning the past 5 years, the laparoscopic approach was used in all cases, with a total of 270 laparoscopically harvested pedicled omentum flaps (LHOF) and 23 free flaps (LHOFF). Fifty-seven complications in 293 patients $(19.4 \%)$ were recorded; three procedures were suspended, one due to severe abdominal adhesions and the other to a vascular injury with flap loss. A fat transplantation was successfully performed.

In both reviews, the total or partial flap necrosis was the most frequent complication, occurring in Claro's 
review in $31.7 \%$ of cases and in our review in only $5.8 \%$.

Likewise, the incidence of wound infection is $19.6 \%$ in Claro's review and only $1.2 \%$ in ours.

The quality of cosmetic results was deemed satisfactory (excellent/good) in 230 and unsatisfactory (fair/poor) in 42 cases. The main reasons for unsatisfactory cosmetic results were breast asymmetry following intraoperative flap necrosis, or partial flap loss, or volume insufficiency.

Volume insufficiency is encountered relatively frequently: Zaha [7] reported $32 \%$ volume insufficiency in 200 patients with a median resected weight of $181 \mathrm{~g}$.

Furthermore, the predictability of flap volume seems to be a problem, as mentioned in all the articles in our review, because neither body mass index nor radiological methods were able to provide precise information, and only laparoscopic exploration proved effective for evaluating this volume, which can be less than $100 \mathrm{~g}$.

As a breast volume smaller than $200 \mathrm{~g}$ is very rare in Caucasian women, this kind of reconstruction is possible only in a small group of patients with unilateral reconstructions. On the other hand, as most Asian women are very thin and small breasted, they are probably better candidates for this procedure. Indeed, six of all seven articles reported on procedures performed in Eastern countries and only one article mentioned procedures performed in Europe, namely with only six patients.

Sandbichler et al. [15] recently reported on an interesting series of patients undergoing breast reconstruction with the omental flap using the laparoscopic approach. This study was not captured with our search strategy, as it was published in a journal not indexed in PubMed. The author reported on 65 consecutive cases from November 2014 to December 2017, including 39 complete subcutaneous and 26 partial subcutaneous mastectomies with a mean operative time of $154 \mathrm{~min}$. However, it is not clear whether the operative time reported included the mastectomy or only flap reconstruction, as we found in our review a significantly longer operative time. Laparoscopic harvesting resulted in gastric perforation and one case of flap loss, while five partial skin necroses and nine volume insufficiencies were also recorded, with a complication rate of $10.77 \%$ and $13.84 \%$ cases of volume insufficiency.

While the option of laparoscopic harvesting may seem appealing, this technique is associated with several limitations including major complications like gastric perforation or vascular injuries, the possibility to repair only one side, long operative time, and the unpredictable weight of the flap that is often insufficient. These limitations should be taken into account when choosing the surgical technique from among other more validated and safe flaps in breast reconstruction.

\section{Conclusion}

According to the available data, the omentum flap can be reasonably used only in one-sided reconstructions of very small breasts or in BCS.

On the one hand, the laparoscopically harvested great omentum flap, pedicled or free, shows smaller complication rates than in the past. On the other hand, the procedure requires an experienced laparoscopic surgeon, is only possible in small-breasted women, and there is currently no means of determining the omentum's volume before surgery.

Operative time was more than 5 hours in LHOF and exceeded 6 hours for free flap transplantation.

Further studies are needed to assess the long-term oncological outcome of omental flap-based breast reconstruction.

In summary, we found improvements in breast reconstruction with the omentum flap during the past 5 years and a decreased number of complications in all publications.

Because of the limited indications, the unpredictable flap volume, and our negative experience with the above-mentioned case report, in our hospital, we continue to perform breast reconstruction with implant/expander or autologous perforator flaps like the DIEP or the PAP flap after skin-/nipple-sparing mastectomy.

Due to the limited indications, unpredictable flap volume, and our negative experience, we recommend that this type of reconstruction be used with restraint.

Funding Open access funding provided by University of Innsbruck and Medical University of Innsbruck.

Conflict of interest R. Spinelli, M. Lanthaler, C. Tasch, A. Nitto, G. Pierer, and T. Bauer declare that they have no competing interests.

Open Access This article is distributed under the terms of the Creative Commons Attribution 4.0 International License (http://creativecommons.org/licenses/by/4.0/), which permits unrestricted use, distribution, and reproduction in any medium, provided you give appropriate credit to the original author(s) and the source, provide a link to the Creative Commons license, and indicate if changes were made.

\section{References}

1. Veronesi U, Cascinelli N, Mariani L, Greco M, Saccozzi R, Luini A, et al. Twenty-year follow-up of a randomized study comparing breast-conserving surgery with radical mastectomy for early breast cancer. N Engl J Med. 2002;347:1227-32.

2. Champaneria MC, Wong WW, Hill ME, Gupta SC. The evolution of breast reconstruction: a historical perspective. World J Surg. 2012;36(4):730-42. https://doi.org/10.1007/ s00268-012-1450-2.

3. Allen RJ, Treece P. Deep inferior epigastric perforator flap for breast reconstruction. Ann Plast Surg. 1994;32:32.

4. Healy C, Allen RJ Sr.. The evolution of perforator flap breast reconstruction: twenty years after the first DIEP flap. 
Reconstr Microsurg. 2014;30(2):121-5. https://doi.org/10. 1055/s-0033-1357272.

5. Atkins D, Eccles M, Flottorp S, Guyatt GH, Henry D, Hill S, et al. Systems for grading the quality of evidence and the strength of recommendations I: critical appraisal of existing approaches. The GRADE Working Group. BMC Health Serv Res. 2004;4(1):38.

6 . Kiricuta I. The use of the great omentum in the surgery of breast cancer. Presse Med. 1963;5(71):15-7.

7. Claro F Jr, Sarian LO, Pinto-Neto AM. Omentum for mammary disorders: a 30-year systematic review. Ann Surg Oncol. 2015;22:2540-50.

8. Zaha H, Abe N, Sagawa N, Unesoko M. Oncoplastic surgery with omental flap reconstruction: a study of 200 cases. Breast Cancer Res Treat. 2017;162:267-74.

9. Van Alphen TC, Fechner MR, Smit JM, Slooter GD, Broekhuysen CL. The laparoscopically harvested omentum as a free flap for autologous breast reconstruction. Microsurgery. 2017;37:539-45.

10. Guan D, Lin H, Lv Z, Xin Y, Meng K, Song X. The oncoplastic breast surgery with pedicled omental flap harvested by laparoscopy: initial experiences from China. World J Surg Oncol. 2015;13:95.
11. Kim H, Yoon CS, Lee HB, Ko BK, Kim GY, Kim KN. Minibreast reconstruction with an omental flap: a retrospective clinical study. ANZ J Surg. 2016; https://doi.org/10.1111/ ans.13701.

12. Li N, Zheng Z, Li J, Fan J, Wang T, Zhang J, et al. Immediate breast reconstruction with omental flap for luminal breast cancer patients: ten clinical case reports. Medicine. 2017;96(e):7797.

13. Zhang P, Luo Y, Deng J, Shao G, Han S, Huang Z. Endoscopic axillary lymphadenectomy combined with laparoscopically harvested pedicled omentum for immediate breast reconstruction. SurgEndosc. 2015;29:1376-83.

14. NiC, ZhuZ, Xin Y, XieQ, Yuan H, Zhong M, etal. Oncoplastic breast reconstruction with omental flap : a retrospective study and systematic review. J Cancer. 2018;9(10):1782-90.

15. Sandbichler, et al. J Clin Exp Oncol. 2018;7:4. https://doi. org/10.4172/2324-9110.1000223.

Publisher's Note Springer Nature remains neutral with regard to jurisdictional claims in published maps and institutional affiliations. 